
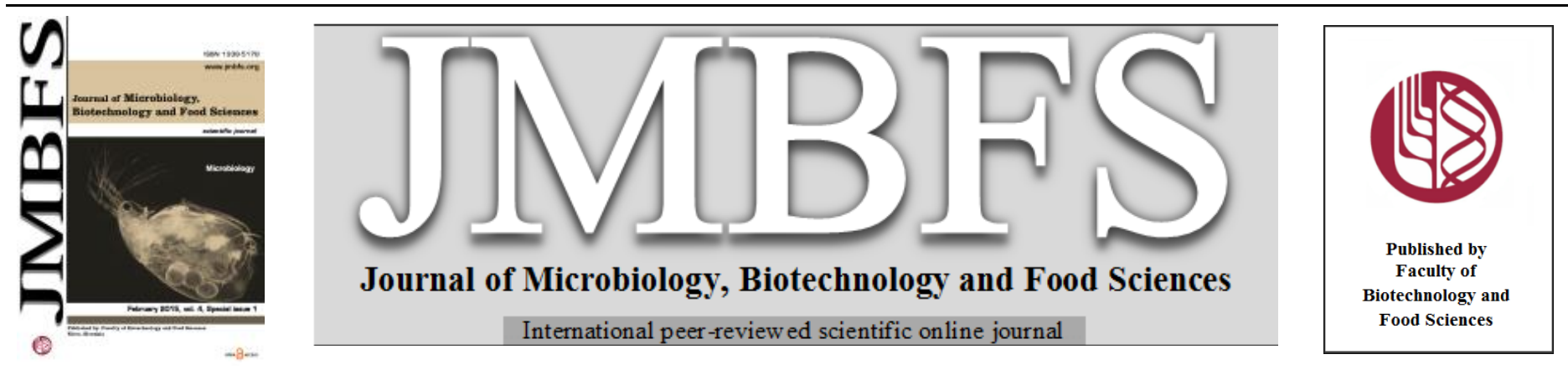

\title{
IMPACT OF ANISE (PIMPINELLA ANISUM) AND MINT (MENTHA PIPERITA) ESSENTIAL OILS TO MICROBIAL ACTIVITY IN CHICKEN MEAT
}

\section{Miroslava Kačániová ${ }^{1}$, Jana Petrová ${ }^{1}$, Martin Mellen ${ }^{2}$, Juraj Čuboň ${ }^{3}$, Peter Haščík ${ }^{3}$, Lukáš Hleba $^{1}$, Margarita Terentjeva ${ }^{4}$, Simona Kunová ${ }^{5}$, Henrieta Blaškovičová ${ }^{1}$}

Address(es): prof. Ing. Miroslava Kačániová, PhD.,

${ }^{1}$ Slovak University of Agriculture in Nitra, Faculty of Biotechnology and Food Sciences, Department of Microbiology, Trieda Andreja Hlinku 2, 949 76, Nitra,

Slovakia.

${ }^{2}$ Hydina Slovakia, s.r.o., Nová L’ubovňa 505, 06511 Nová L'ubovňa, Slovakia.

${ }^{3}$ Slovak University of Agriculture in Nitra, Faculty of Biotechnology and Food Sciences, Department of Animal Products Evaluation and Processing, Tr. A. Hlinku 2, 94976 Nitra, Slovak Republic.

${ }^{4}$ Latvia University of Agriculture, Faculty of Veterinary Medicine, Institute of Food and Environmental Hygiene, K. Helmana iela 8, LV 3007, Jelgava, Latvia.

${ }^{5}$ Department of Food Hygiene and Safety, Faculty of Biotechnology and Food Sciences, Slovak University of Agriculture in Nitra, Trieda Andreja Hlinku 2, 94976

Nitra, Slovak Republic.

*Corresponding author: miroslava.kacaniova@gmail.com

doi: 10.15414/jmbfs.2015.4.special1.28-31

\section{ARTICLE INFO}

Received 12.11.2014

Revised 11. 12. 2014

Accepted 16. 12. 2014

Published 2. 2. 2015

Regular article

open $\partial_{\text {ACCESS }}$

\section{ABSTRACT}

The goal of the present study was to evaluate fresh chicken thighs quality (microbiological and sensory) after treatment by ethylenediaminetetraacetate (EDTA), Pimpinella anisum L. and Mentha piperita essential oils in $1 \%$ concentration, stored under vacuum packaging (VP), at $4 \pm 0.5^{\circ} \mathrm{C}$ for a period of 16 days. The following treatments of chicken thighs were applied: air-packaged (AC, control samples), vacuum-packaged (VPC, control samples), vacuum-packed with EDTA solution 1.50\% v/w (VPEC, control samples), VP with Pimpinella anisum L. and Mentha piperita essential oil at concentrations $0.1 \% \mathrm{v} / \mathrm{w}$ (VP+AEO and VP+MEO). The quality assessment of VP product after EDTA treatment, Pimpinella anisum L. and Mentha piperita oils was done by microbiological testing and the total viable counts, Enterobacteriaceae, lactic acid bacteria and Pseudomonas aeruginosa were detected. The using of Pimpinella anisum $\mathrm{L}$. and Mentha piperita oils and EDTA with combination of vacuum packaging has significant effect $(\mathrm{P}<0.05)$ to reduction of microorganisms compared with control group without vacuum packaging and untreated control group.

Keywords: Anise, mint, essential oil, antimicrobial effect, chicken thigh

\section{INTRODUCTION}

Essential oils are volatile, natural, complex compounds characterized by a strong odour and are formed by aromatic plants as secondary metabolites. They are usually obtained by steam or hydro-distillation. Known for their antiseptic, i.e. bactericidal, virucidal and fungicidal, and medicinal properties and their fragrance, they are used in embalming, preservation of foods and as antimicrobial, analgesic, sedative, anti-inflammatory, spasmolytic and locally anesthesic remedies. Up to the present day, these characteristics have not changed a lot with exception that more is now known about some of their mechanisms of action, particularly regarding the antimicrobial activity. In nature, essential oils play an important role in the protection of the plants as antibacterials, antivirals, antifungals, insecticides substances and also against herbivores by reducing their appetite for such plants. They also may attract some insects to favor the dispersion of pollen and seeds, or repel undesirable others. Essential oils are extracted from various aromatic plants and the plants generally are grown in countries with temperate to warm climate like Mediterranean and tropical countries where they represent an important part of the traditional pharmacopoeia. They are liquid, volatile, limpid and rarely colored, lipid soluble and soluble in organic solvents with a generally lower density than that of water They can be synthesized by all plant organs, i.e. buds, flowers, leaves, stems, twigs, seeds, fruits, roots, wood or bark, and are stored in secretory cells, cavities, canals, epidermic cells or glandular trichomes (Bakkali et al., 2007).

The antimicrobial activity of the essential oils has been examined in studies against Gram-negative bacteria, demonstrating high antimicrobial capacity (Sharafi et al., 2010; Panghal et al., 2011). Clinical studies using the essential oils are scarce; they have been tested mainly topically on skin and mucous membranes (Van Vuuren et al., 2010). Additionally, there is little information regarding safety in relation to the oral administration of essential oils (Solorzano-Santos and Miranda-Novales, 2012). Currently, essential oils represent a source of natural antimicrobial substances, which may be used in the food industry as biopreservatives to prevent food spoilage and to prolong the shelf life of products. Furthermore, the essential oils could reduce side effects caused by the use of chemical preservatives (Sharafi et al., 2010). It is generally accepted that phenolic compounds-having the hydroxyl group attached to a phenyl ring-have the greatest antimicrobial activity among the secondary metabolites found in essential oils (Dorman and Deans, 2000; Lambert et al. 2001). Such examples are the monoterpenes carvacrol and thymol and the phenylpropene eugenol (Benchaar et al., 2009). In addition, non-phenolic secondary metabolites found in essential oils have a variable antimicrobial capacity.

Anise (Pimpinella anisum L.), which is an aromatic plant, was used for its stimulating effects on digestion and its antiparasitic (Cabuk et al., 2003), antibacterial (Singh et al., 2002; Tabanca et al., 2003), antifungal (Soliman and Badeaa, 2002), antipyretic (Afifin et al., 1994) and laxative (Chicouri and Chicouri, 2000) properties. Additionally, the plant was used in the treatment of some disease like seizures and epilepsy (Abdul-Ghani et al., 1984; Avicenna, 1988). Furthermore, it has been shown to have anticonvulsant (Debersac et al., 1995) and muscle relaxant effects (Albuquerque et al., 1995).

Mint (Mentha) is an herb used extensively in Indian cuisine and also for curing several common ailments (Choudhury et al., 2006). Earlier studies in our laboratory showed that mint extract had very good antioxidant potential, which was comparable to that of the synthetic antioxidant, butylated hydroxy toluene (BHT) (Kanatt et al., 2007). Mint extract did not show any antibacterial activity, however essential oils of some Mentha species have been reported to have antibacterial activity (Marino et al., 2001; Moreira et al., 2005).

In this study we aimed to investigate the combined effect of ethylenediaminetetraacetate (EDTA) and Pimpinella anisum L. and Mentha piperita essential oils at $0.1 \%$ concentration, on the shelf-life extension of fresh 
chicken thighs stored under vacuum packaging (VP), at $4 \pm 0.5^{\circ} \mathrm{C}$ for a period of 16 days.

\section{MATERIAL AND METHODS}

\section{Preparation of samples}

To evaluate the antimicrobial activity of essential oils the chicken thigh with skin of each experimental group was taken. The chicken thigh fresh samples with were prepared as follow: for air-packaging (AC, control samples) chicken thigh fresh meat was packaged to polyethylene bags and stored aerobically in refrigerator; for vacuum-packaged (VPC, control samples) chicken thigh fresh meat was packaged to polyethylene bags and stored anaerobically in vacuum and in refrigerator; for vacuum-packed samples with EDTA solution $1.5 \% \mathrm{w} / \mathrm{w}$ (VPEC, control samples) chicken thigh fresh meat was treated with EDTA for 1 min and packaged to polyethylene bags and stored anaerobically in vacuum and in refrigerator; for vacuum-packed samples with Pimpinella anisum L.oil $0.10 \%$ $\mathrm{v} / \mathrm{w}(\mathrm{VP}+\mathrm{AEO})$ chicken thigh fresh meat was treated with anise oil for $1 \mathrm{~min}$ and packaged to polyethylene bags and stored anaerobically in vacuum and in refrigerator; for vacuum-packed samples with Mentha piperita oil $0.10 \% \mathrm{v} / \mathrm{w}$, (VP+MEO) chicken thigh fresh meat was treated with mint oil for $1 \mathrm{~min}$ and packaged to polyethylene bags and stored anaerobically in vacuum and in refrigerator $\left(4 \pm 0.5^{\circ} \mathrm{C}\right)$. For sample packaging a vacuum packaging machine type VB-6 (RM Gastro, Czech Republic) was used and each sample were packed immediately after treatment.

A stock solution of $500 \mathrm{mM}$ concentration of EDTA was prepared by diluting $186.15 \mathrm{~g}$ in $1 \mathrm{~L}$ distilled water (EDTA, $\left(\mathrm{C}_{10} \mathrm{H}_{14} \mathrm{~N}_{2} \mathrm{O}_{8} \cdot \mathrm{Na}_{2} \cdot 2 \mathrm{H}_{2} \mathrm{O}\right.$ ), $99.5 \%$ purity, analytical grade, (Invitrogen, USA). A final concentration of $50 \mathrm{mM}$ EDTA solution was prepared from the stock solution. The $\mathrm{pH}$ of the solution was adjusted to 8.0 with the addition of the appropriate quantity of $\mathrm{NaOH}$ solution Anise and mint essential oil (Calendula, Nova Lubovna, Slovakia) was added to coat chicken thigh surface (both sides) of each sample using a micropipette. Final concentration of $0.1 \% \mathrm{v} / \mathrm{w}$ of EO was used for treatment.

\section{Microbiological analysis}

Approximately $10 \mathrm{~g}\left(10 \mathrm{~cm}^{2}\right)$ of the chicken thigh was sampled using sterile scalpels and forceps, immediately transferred into a sterile stomacher bag, containing $90 \mathrm{~mL}$ of $0.1 \%$ peptone water $(\mathrm{pH} 7.0)$, and homogenized for $60 \mathrm{~s}$ in a Stomacher at room temperature. Sampling was carried out after certain time intervals: $0,4,8,12$ and 16 days. Chicken thigh were stored under vacuum packaging, at $4 \pm 0.5^{\circ} \mathrm{C}$ during experiment.

Microbiological analyses were conducted by using standard microbiological methods. Total viable counts (TVC) were determined using Plate Count Agar (PCA, Oxoid, UK), after incubation for 2 days at $37^{\circ} \mathrm{C}$. For Pseudomonas aeruginosa enumerations, $0.1 \mathrm{~mL}$ from 1:10 prepared serial dilutions $(0.1 \%$ physiological solution) of chicken homogenates was spread onto the surface of solid media. Pseudomonas were determined on Pseudomonas Isolation agar (PIA, Oxoid, UK) after incubation at $48 \mathrm{~h}$ at $25^{\circ} \mathrm{C}$. The typical Pseudomonas colonies were detected by producing of blue or blue-green pyocyanin pigment by Pseudomonas aeruginosa and the pigment diffuses into the medium surrounding growth. For lactic acid bacteria enumeration, a $1.0 \mathrm{~mL}$ sample were inoculated into Rogosa and Sharpe agar (MRS, Oxoid, UK) after incubation $48-78 \mathrm{~h}$ at $37^{\circ} \mathrm{C}$ in an aerobic atmosphere supplemented with carbon dioxide $\left(5 \% \mathrm{CO}_{2}\right)$. For members of the family Enterobacteriaceae, a $1.0 \mathrm{~mL}$ sample was inoculated into $10 \mathrm{~mL}$ of molten $\left(45^{\circ} \mathrm{C}\right)$ violet red bile glucose agar (VRBL, Oxoid, UK). After setting, a $10 \mathrm{~mL}$ overlay of molten medium was added and samples incubated at $37^{\circ} \mathrm{C}$ for $24 \mathrm{~h}$. The large colonies with purple haloes were counted. All plates were examined for typical colony types and morphology characteristics associated with each medium applied for incubation.

\section{Statistical analysis}

Mean for each replication was calculated and data were log transformed. The statistical analysis of the data obtained from each evaluation was done with Statgraphics Plus version 5.1 (AV Trading, Umex, Dresden, Germany). Significant differences were calculated using Student's t-test. Confidence limits were added at $\mathrm{P}<0.05 ; \mathrm{P}<0.01 ; \mathrm{P}<0.001$.

\section{RESULTS AND DISCUSSION}

Aromatic plants, their extracts and essential oils contain a variety of functional bioactive compounds, which have possible applications in the food, feed, pharmaceutical and cosmetic industries. However, aromatic plants and their extracts should be standardized and properly controlled in their extraction and composition, in order for the study of these plants to yield meaningful data. In vitro studies using standardized extracts should be completed prior to in vivo experimental research, to confirm the efficacy of the extracts. In this way, viable alternative methods for enhancing performance or improving shelf-life of the animal products may be developed, satisfying the consumer's demands for natural, safe and high quality foods (Christaki et al., 2012).

The antimicrobial activity of essential oil has been known for many centuries. Total vialable counts values for the tested groups of chicken thigh are showed in Fig. 1. The initial TVC value of chicken thigh was $3.68 \pm 0.12 \mathrm{log} \mathrm{cfu} / \mathrm{g}$ (day 0 ), and this finding indicates acceptable quality of poultry products of $10^{7} \mathrm{cfu} / \mathrm{g}$ (Senter et al., 2000). Ismail et al. 2000 reported mean TVC populations of 3.32$5.77 \mathrm{log} \mathrm{cfu} / \mathrm{g}$ for various raw and processed chicken products. A high fat content appears to markedly reduce the action of EOs in meat products. We observed the highest TVC in samples AC and VPC, 6.98 $\pm 0.06 \mathrm{log} \mathrm{cfu} / \mathrm{g}$ and $6.84 \pm 0.26 \mathrm{log}$ cfu/g (day 16), respectively. Economou et al. 2009 in their study reported, that total viable counts (TVC), Pseudomonas spp., Brochothrix thermosphacta, lactic acid bacteria (LAB) and Enterobacteriaceae counts for all EDTA-treated chicken samples were similar to the control samples with no statistically significant differences between combination nisin-EDTA treatments. Statistically significant difference after fourth day $(\mathrm{P}<0.05)$ was found between $\mathrm{AC}$ and $\mathrm{VP}+\mathrm{MAO}$; $\mathrm{AC}$ and $\mathrm{VP}+\mathrm{AE} 0$. Statistically significant differences after eighth day $(\mathrm{P}<0.05)$ were found between $\mathrm{AC}$ and $\mathrm{VP}+\mathrm{MAO} ; \mathrm{AC}$ and $\mathrm{VP}+\mathrm{AEO}$ and $\mathrm{AC}$ and $\mathrm{VPC}$. Statistically significant differences was found also after $12^{\text {th }}$ and $16^{\text {th }}$ day.

In our study, with respect to Enterobacteriaceae, considered as a hygiene indicator (Zeitoun et al., 1994), the initial (day 0) counts were $0.00 \pm 0.00 \log$ cfu/g indicating the good quality of chickens meat. On day 16 of storage Enterobacteriaceae family reached $6.32 \pm 0.09 \mathrm{log} \mathrm{cfu} / \mathrm{g}$ in control samples. In the case VPC, the count of Enterobacteriaceae ranged from $0.00 \pm 0.00 \mathrm{log}$ cfu/g (day $0)$ to $5.93 \pm 0.15 \mathrm{log}$ cfu/g (day 16) (Figure 2). The number of Enterobacteriaceae $5.74 \pm 0.37 \mathrm{log} \mathrm{cfu} / \mathrm{g}$ had been found only in 16 day of evaluation in the case of the storage under the package with EDTA. Statistically significant differences $(\mathrm{P}<0.05)$ were not found between all tested group in fourth day.

$\mathrm{LAB}$ behaves as facultative anaerobes and can able to grow under high concentrations of $\mathrm{CO}_{2}$. Thus they constitute a substantial part of the natural microflora of VP meats. LABs are recognized as the important competitors of the other spoilage related microbial groups under VP/MAP conditions (Zhang $\boldsymbol{e t}$ al., 2009; Doulgeraki et al., 2011; Castellano et al., 2004). Particularly, Lactobacillus spp., Carnobacterium spp. and Leuconostoc spp. are associated to the spoilage of refrigerated raw meat (Nychas and Skandamis, 2005). More species of lactobacilli can be found during the storage under the vacuum at $4^{\circ} \mathrm{C}$ including $L b$. algidus beyond $L b$. sakei. The results of Ntzimani et al. (2010) indicate that $\mathrm{LAB}$ was an important part of the precooked chicken microflora, irrespective of the packaging conditions and the antimicrobial treatment combination. The latter observations could probably help to explain their rapid growth between days 0 and 2 of storage. This is also in agreement with LAB growth in beef stored under MAP at $5^{\circ} \mathrm{C}$ (Skandamis and Nychas, 2001).

The initial number of lactic acid bacteria counts (Fig. 3) was $1.88 \pm 0.49 \mathrm{log} \mathrm{cfu} / \mathrm{g}$ (day 0). The number of lactic acid bacteria in control group was ranged from $2.53 \pm 0.44 \log \mathrm{cfu} / \mathrm{g}$ (day 0) to $3.69 \pm 0.78 \mathrm{log} \mathrm{cfu} / \mathrm{g}$ (day 16). In the case of VPC the highest count of lactic acid bacteria of $3.79 \pm 0.34 \mathrm{log} \mathrm{cfu} / \mathrm{g}$ was detected on day 16 of storage; in VPEC group - 4.07 $\pm 0.30 \mathrm{log} \mathrm{cfu} / \mathrm{g}$ (day 16); in VP+AEO group - 3.40 $\pm 0.41 \mathrm{log} \mathrm{cfu} / \mathrm{g}$ (day 16) and in VP+MEO group - $4.27 \pm 0.15 \log$ $\mathrm{cfu} / \mathrm{g}$ (day 16) of storage. The fact that foodstuff components always act protectively on microorganisms as compared to pure cultures (Burt, 2004).

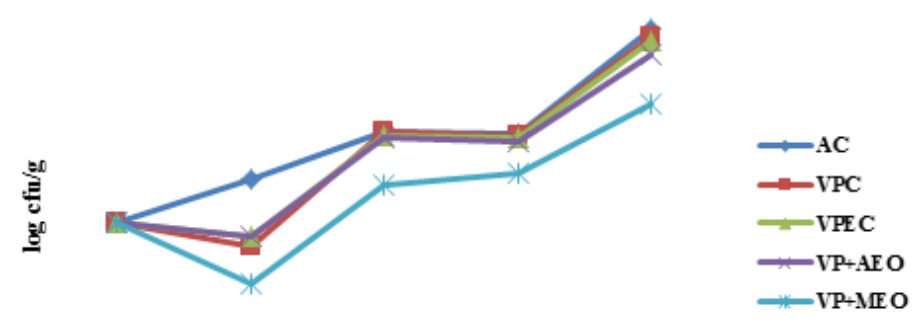

\section{Incubation on days}

Figure 1 Changes $(\log \mathrm{cfu} / \mathrm{g})$ in population of Total Viable Count in chicken thigh stored in air (AC); stored under vacuum (VP); stored under vacuum packaging with EDTA (VPEC); stored under vacuum packaging with Pimpinella anisum L. 0.1\% essential oil (VP+EA0); stored under vacuum packaging with Mentha piperita $0.1 \%$ essential oil (VP+MA0) 


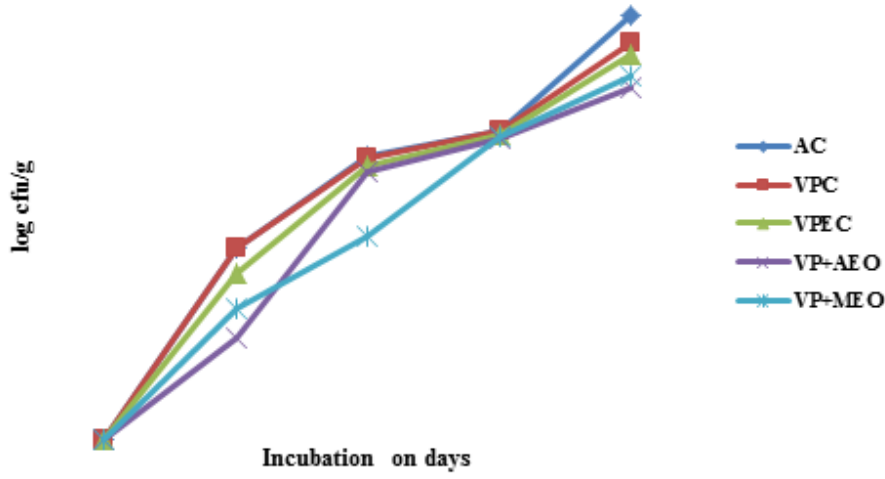

Figure 2 Changes (log cfu/g) in population of Enterobacteriacae in chicken thigh stored in air (AC); stored under vacuum (VP); stored under vacuum packaging with EDTA (VPEC); stored under vacuum packaging with Pimpinella anisum L. $0.1 \%$ essential oil (VP+EA0); stored under vacuum packaging with Mentha piperita $0.1 \%$ essential oil (VP+MA0)

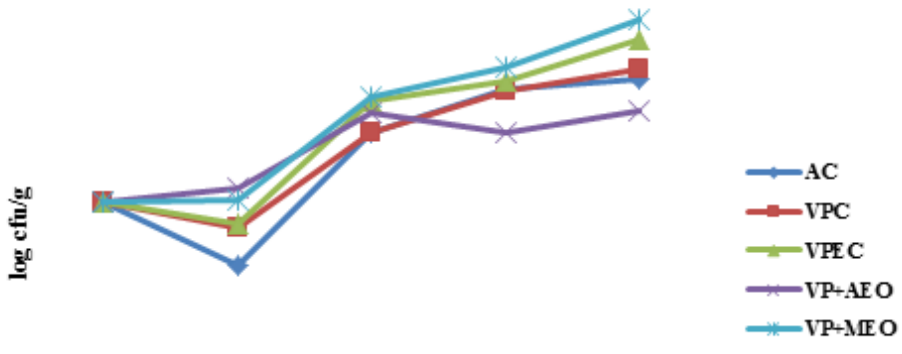

Incubation on days

Figure 3 Changes (log cfu/g) in population of lactic acid bacteria in chicken thigh stored in air (AC); stored under vacuum (VP); stored under vacuum packaging with EDTA (VPEC); stored under vacuum packaging with Pimpinella anisum L. $0.1 \%$ essential oil (VP+EA0); stored under vacuum packaging with Mentha piperita $0.1 \%$ essential oil (VP+MA0)

Of the gram-negative bacteria, Pseudomonads, and in particular $P$. aeruginosa, appear to be less sensitive to the action of EOs (Wilkinson et al., 2003). Bioactive components of plant-origin antimicrobials are relatively weak against Pseudomonas spp. Thus, VP and MAP inhibit the growth of pseudomonads, as compared to air packaging. It is believed that VP extends the lag phase of aerobic microbial growth and decreases growth rate during the logarithmic phase. For example, VP reduced the Pseudomonads by $1.3 \log \mathrm{cfu} / \mathrm{g}$ on day 16 of storage and kept their populations under $2 \log$ cfu/g until day 16 of storage. It has been reported that due to cell wall composition, Gram negative bacteria are less sensitive to EOs than Gram-positive bacteria even Burt, 2004 repoerted the opposite. The essential oils from leaves of the three Pinus species inhibited the bacterial growth. The essential oils from $P$. thunbergii and $P$. rigida showed bactericidal activity after $4 \mathrm{~h}$. Previous work showed that the essential oils from $P$. densiflora and $P$. thunbergii had moderate inhibitory activity and the essential oil from P. caribeae exhibited antimicrobial activity (Sonibare and Olakunle, 2008). In our study the initial count of Pseudomonas aeruginosa was $0 \pm 0.00 \log$ $\mathrm{cfu} / \mathrm{g}$ in all group during all testing period.

\section{CONCLUSION}

The results of this present study suggest the possibility of using the essential oil of Pimpinella anisum L. and Mentha piperitaas as natural food preservatives and potential source of antimicrobial ingredients for meat. Of the antimicrobial combination treatments examined in the work, the use of storage condition as vacuum packaging, EDTA, and essential oils were the most effective against the growth of lactic acid bacteria and Enterobactericeae family and to a less extent on total viable count. Based on microbiological analyses, treatments with Pimpinella anisum L. and Mentha piperita essential oils resulted in shelf-life extension, as compared to the control samples. Therefore, the combined effect of essential oil and vacuum packaging on the safety and sensory properties of the meat could be investigated.
Acknowledgments: The paper was supported by the project: The research leading to these results has received funding from the European Community under project no 26220220180: Building Research Centre „AgroBioTech“, by grant of VEGA 1/0611/14

\section{REFERENCES}

ABDUL-GHANI, A.S., EL-LATI, S.G., SACAAN, A.I., SULEIMAN, M.S 1987. Anticonvulsant effects of some Arab medicinal plants. International Journal of Crude Drug Research, 25, 39-43. http://dx.doi.org/10.3109/13880208709060909

AFIFI, N.A., RAMADAN, A., EL-KASHOURY, E.A., EL-BANNAH. A. 1994 Some pharmacological activities of essential oils of certainumbelliferous fruits. Veterinary Medical Journal Giza, 42, 85-92.

ALBUQUERQUE, A.A., SORENSON, A.L., LEAL-CARDOSO, J. H. 1995. Effects of essential oil of Croton zehntneri and of anethole and estragole on skeletal muscles. Journal of Ethnopharmacology, 49,41-49. http://dx.doi.org/10.1016/0378-8741(95)01301-6

AVICENNA A.: Drugs and decoctions used in epilepsy. In: Sharafkandi, A (Translator), Ghanoon Dar Teb. Soroosh Press,Tehran, 1988, 456-459.

BAKKALI, F., AVERBECK, S., AVERBECK, D., IDAOMAR, M. 2008 Biological effects of essential oils - A review. Food and Chemical Toxicology, 46(2), 446-475. http://dx.doi.org/10.1016/j.fct.2007.09.106

BENCHAAR, C., HRISTOV, A.N., GREATHEAD, H. 2009. Essential oils as feed additives in ruminant nutrition. Phytogenics in Animal Nutrition, 111-146. http://dx.doi.org/10.7313/upo9781904761747.008

BURT, S. 2004. Essential oils: their antibacterial properties and potential applications in foods-a review. International Journal of Food Microbiology, 94(3), 223-253. http://dx.doi.org/10.1016/j.ijfoodmicro.2004.03.022

CABUK, M., ALCICEK, A., BOZKURT, M., IMRE, N. 2003. Antimicrobial properties of the essential oils isolated from aromaticplants and using possibility as alternative feed additives. In: II. National Animal Nutrition Congress, 18-20 September, 184-187.

CASTEllanO, P. H., HOLZAPFEL, W. H., VINGOLO, G. M. 2004. The control of Listeria innocua and Lactobacillus sakei in broth and meat slurry with the bacteriocinogenic strain Lactobacillus casei CRL705. Food Microbiology, 21(3), 291-298. http://dx.doi.org/10.1016/j.fm.2003.08.007

DEBERSAC, P., VERNEVAUT, M.F., AMIOT, M.J., SUSCHETET, M., SIESS M. H. 1995. Effects of a water soluble extract of rosemary and its purified component rosmarinic acid on xenobiotic-metabolizing enzymes in rat liver Food Chemistry and Toxicology, 29,109-117. http://dx.doi.org/10.1016/s02786915(00)00117-4

DORMAN, H.J.D., DEANS, S.G. 2000. Antimicrobial agents from plants: Antibacterial activity of plant volatile oils. Journal of Applied Microbiology, 88 308-316. http://dx.doi.org/10.1046/j.1365-2672.2000.00969.x

DOULGERAKI, A. I., PARAMITHIOTIS, S., \&NYCHAS, G. J. E. (2011) Characterization of the Enterobacteriaceae community that developed during storage of minced beef under aerobic or modified atmosphere packaging conditions. International Journal of Food Microbiology, 145(1), 77-83. http://dx.doi.org/10.1016/j.ijfoodmicro.2010.11.030

ECONOMOU, T., POURNIS, N., NTZIMANI, A., SAVVAIDIS, I. N. 2009 Nisin-EDTA treatments and modified atmosphere packaging to increase fresh chicken meat shelf-life. Food Chemistry, 114(4), 1470-1476. http://dx.doi.org/10.1016/j.foodchem.2008.11.036

GIANNENAS, I. 2008. How to use plant extracts and phytogenics in animal diets. World Nutrition Forum, the Future of Animal Nutrition; Binder, E.M., Schatzmayr, G., Eds.; NottinghamUniversity Press: Nottingham, UK, 111-129.

CHICOURI, M., CHICOURI, I. 2000. Novel pharmaceutical compositions containing senna with laxative effect. Fr. Demande FR 2791892 A1, Oct 13, 2000, 6 pages.

CHOUDHURY, R.P., KUMAR, A., GARG, A.N. 2006. Analysis of Indian mint (Mentha spicata) for essential, trace and toxic elements and its antioxidant behaviour. Journal of Pharmaceutical and Biomedical Analysis, 41, 825-832. http://dx.doi.org/10.1016/j.jpba.2006.01.048

CHRISTAKI, E., BONOS, E., GIANNENAS, I., FLOROU-PANERI, P. 2012. Aromatic Plants as a Source of Bioactive Compounds Agriculture, 2, 228-243. http://dx.doi.org/10.3390/agriculture2030228

ISMAL, S. A. S., DEAK, T., ABD EL-RAHMAN, H. A., YASSIEN, M., A. M., BEUCHAT, L. R. 2000. Presence and changes in populations of yeasts on raw and processed poultry products stored at refrigeration temperature. International Journal of Food Microbiology, 62(1-2), 113-121. http://dx.doi.org/10.1016/s0168-1605(00)00414-1

KANATT, S. R., CHANDER, R., SHARMA, A. 2007. Antioxidant potential of mint (Mentha spicata L.) in radiation processed lamb meat. Food Chemistry, 100 , 451-458. http://dx.doi.org/10.1016/j.foodchem.2005.09.066

LAMBERT, R.J.W., SKANDAMIS, P.N., COOTE, P.J., NYCHAS, G.J.E. 2001. A study of the minimuminhibitory concentration and mode of action of oregano essential oil, thymol and carvacrol. Journal of Applied Microbiology, 91, 453462. http://dx.doi.org/10.1046/j.1365-2672.2001.01428.x 
MARINO, M., BERSANI, C., COMI, G: 2001. ComiImpedance measurements to study the antimicrobial activity of essential oils from Lamiaceae and Compositae. International Journal of Food Microbiology, 67, 187-195. http://dx.doi.org/10.1016/s0168-1605(01)00447-0

MOREIRA, M.R., PONCE, A.G., DEL VALLE, C.E., ROURA, S.I. 2005. Inhibitory parameters of essential oils to reduce a foodborne pathogen. Lebensmittel, 38, 565-570. http://dx.doi.org/10.1016/j.1wt.2004.07.012

NYCHAS, G. J. E., SKANDAMIS, P. 2005. Fresh meat spoilage and modified atmosphere packaging (MAP). In: Sofos, J.N. (Ed.), Improving the Safety of Fresh Meat. CRC/ Woodhead Publishing Limited, Cambridge, 461-502. http://dx.doi.org/10.1533/9781845691028.2.461

NTZIMANI, A. G., GIATRAKOU, V. I., \&SAVVAIDIS, I. N. 2010. Combined natural antimicrobial treatments (EDTA, lysozyme, rosemary and oregano oil) on semi cooked coated chicken meat stored in vacuum packages at $4^{\circ} \mathrm{C}$ : Microbiological and sensory evaluation. Innovative Food Science and Emerging Technologies, 11(1), 187-196. http://dx.doi.org/10.1016/j.ifset.2009.09.004

PANGHAL, M., KAUSHAL, V., YADAV, J.P. 2011. In vitro antimicrobial activity of ten medicinal plantsagainst clinical isolates of oral cancer. Annals of Clinical Microbiology and Antimicrobials, 10, 20-21. http://dx.doi.org/10.1186/1476-0711-10-21

POURGHOLAM, M.H., MAJZOOB, S., JAVADI, M., KAMALINEJAD, M., FANAEE, G.H., SAYYAH, M. 1999. The fruit essential oil of Pimpinella anisum exerts anticonvulsant effects in mice. Journal Enthnopharmacolgy, 66, 211-215. http://dx.doi.org/10.1016/s0378-8741(98)00161-5

SENTER, S. D., ARNOLD, J. W., CHEW, V. 2000. APC values and volatile compounds formed in commercially processed, raw chicken parts during storage at 4 and $13^{\circ} \mathrm{C}$ under simulated temperature abuse conditions. Journal of the Science Food and Agriculture, 80(10), 1559-1564. http://dx.doi.org/10.1002/1097-0010(200008)80:10<1559::aid-jsfa686>3.0.co;28

SHARAFI, S.M., RASOOLI, I., OWLIA, P., TAGHIZADEH, M., ASTANEH, S.D. 2010. Protective effects ofbioactive phytochemicals from Mentha piperita with multiple health potentials. Pharmacogn Magazine, 6, 147-153 http://dx.doi.org/10.4103/0973-1296.66926

SINGH G., KAPOOR I.P., PANDEY S.K., SINGH U.K., SINGHR.K. 2002 Studies on essential oils: part 10; antibacterial activity of volatile oils of some spices. Phototherapeutic Research, 16, 680-682. http://dx.doi.org/10.1002/ptr.951

SKANDAMIS, P., NYCHAS, G. J. 2001. Effect of oregano essential on microbiological and physicochemical attributes of minced meat stored in air and modified atmospheres. Journal of Applied Microbiology, 91(6), 1011-1022. http://dx.doi.org/10.1046/j.1365-2672.2001.01467.x

SOLIMAN K.M., BADEAA R.I. 2002. Effect of oil plants on differentmycotoxigenic fungi. Food Chemistry Toxicology, 40, 1669-1675. http://dx.doi.org/10.1016/s0278-6915(02)00120-5

SOLORZANO-SANTOS, F., MIRANDA-NOVALES, M.G. 2012. Essential oils from aromatic herbs asantimicrobial agents. Currunt Opinion Biotechnology, 23, 136-141. http://dx. doi.org/10.1016/j.copbio.2011.08.005

SONIBARE, O. O., OLAKUNLE, K. 2008. Chemical composition and antibacterial activity of the essential oil of Pinus caribaea from Nigeria. African $\begin{array}{llll}\text { Journal of } & \text { Biotechnology, } & \text { 2462-2464 }\end{array}$ http://dx.doi.org/10.1080/0972060x.2014.884759

TABANCA N., BEDIR E., KIRIMER N., BASER K.H., KHANS.I., JACOB M.R., KHAN I.A. 2003. Antimicrobial compounds from Pimpinella species growing in Turkey. Planta Medical, 69,933-938. http://dx.doi.org/10.1055/s2003-45103

VAN VUUREN, S.F., DU TOIT, L.C., PARRY, A., CHOONARA, Y.E. 2010 Encapsulation of essential oils withina polymeric liposomal formulation for enhancement of antimicrobial efficacy. Natural Product Communication, 5, 1401-1408.

WILKINSON, J. M., HIPWELL, M., RYAN, T., CAVANAGH, H. M. A. 2003. Bioactivity of Backhousia citriodora: Antibacterial and antifungal activity. Journal of Agricultural and Food Chemistry, 51(1), 76-81. http://dx.doi.org/10.1021/jf0258003

ZHANG, H., KONG, B., XIONG, Y. L., SUN, X. 2009. Antimicrobial activities of spice extracts against pathogenic and spoilage bacteria in modified atmosphere packaged fresh pork and vacuum packaged ham slices stored at $4{ }^{\circ} \mathrm{C}$. Meat Science, 81(4), 686-692. http://dx.doi.org/10.1016/j.meatsci.2008.11.011 